\title{
Preclinical and clinical experiences with the role of somatostatin receptors in the treatment of pituitary adenomas
}

\author{
Joost van der Hoek, Steven W J Lamberts and Leo J Hofland \\ Department of Internal Medicine, Section Endocrinology, Room Ee30b, Erasmus MC, Dr Molewaterplein 50, 3015 GE, Rotterdam, The Netherlands \\ (Correspondence should be addressed to L J Hofland; Email: 1.hofland@erasmusmc.nl)
}

\begin{abstract}
The patho-physiological role of somatostatin receptor subtypes (sst) in neuro endocrine diseases has gained enhanced scientific interest in the past few years. The development of novel somatotropinrelease inhibiting factor analogs, both sst-specific and universal ligands, seem promising as a tool to further increase fundamental insights in sst function. Eventually, this research should result in novel medical therapeutic opportunities in patients suffering from neuro-endocrine diseases. In the present review, the functional role of sst in all types of pituitary adenomas, based on recent preclinical and clinical studies, is being discussed.
\end{abstract}

European Journal of Endocrinology 156 S45-S51

\section{Introduction}

Somatostatin, also known as somatotropin-release inhibiting factor (SRIF), is a cyclopeptide that has broad inhibitory effects on the secretion of hormones such as growth hormone, insulin and glucagon. These effects have formed the basis for the clinical use of SRIFanalogs in the treatment of acromegaly and endocrine tumors. The discovery of the five SRIF receptor subtypes (sst) in the 1990s further enhanced the understanding of the biological roles of SRIF and SRIF analogs, and paved the way for new therapeutic opportunities. In this review, recent preclinical and clinical advances in ssttargeted treatment of human pituitary adenomas are discussed.

\section{GH-secreting pituitary adenomas}

Acromegaly is predominantly caused by a growth hormone $(\mathrm{GH})$ secreting pituitary adenoma, resulting in high circulating GH and insulin-like growth factor I (IGF-I) hormone concentrations. Over the years, a triad of therapeutical options has been formed: surgery, irradiation and medical treatment (1). These treatment modules had the aim of inducing tumor shrinkage and normalizing GH and IGF-I levels, thereby reducing the risk of long-term complications including the development of malignant neoplasms, cardio- and

This paper was presented at a symposium held at the Erasmus Medical Center, Rotterdam, The Netherlands, 2005. The symposium was jointly organized by LJ Hofland, Erasmus Medical Center, and A Colao, Federico II University of Naples, Italy. Ipsen partially supported the publication of these proceedings. cerebrovascular disease, respiratory and metabolic dysfunction (2). The clinical introduction of the longacting SRIF analogs in the early 1980s added a new dimension to the treatment of acromegaly (3-5). The short half-life of SRIF and the subsequent need for i.v. administration however, as well as the post-infusion hypersecretion of $\mathrm{GH}$, insulin and glucagon, has rendered the native peptide impractical for therapeutic use (6). The short stable synthetic octapeptide SRIF analogs, octreotide (OCT) and lanreotide, appeared not to have these disadvantages and were administered in acromegalic patients to assess their role as a novel treatment option in acromegaly. Indeed, after the first reports that demonstrated the long-acting inhibitory effect of OCT on plasma GH levels, as well as a rapid amelioration of the clinical signs and symptoms, 20 years of endocrine practice and science has turned OCT and lanreotide into the widely accepted first medical treatment option for acromegaly (7).

The current clinically available octapeptide SRIF analogs have been consistently shown to be able to reduce hormonal hypersecretion and to normalize IGF-I levels in a significant proportion of treated patients. Recently, Freda, summarizing the literature data on this topic (8), showed the achievement of safe GH levels in 56\% of patients treated with sandostatin-LAR (OCT incorporated into microspheres of a biodegradable polymer that results in therapeutical blood concentrations of the peptide for 24-42 days) and in $49 \%$ of those treated with lanreotide $30 \mathrm{mg}$. The respective figures for IGF-I normalization were 66 and $48 \%$. However, a large majority of the patients enrolled in these studies were preselected for SRIF analog responsiveness (8). Therefore, several studies were 
initiated in which newly diagnosed patients were treated with somatostatin analogs. To date, efficacy numbers have been reported for normalizing $\mathrm{GH}(43-79 \%)$ and IGF-I (53-68\%), which are comparable with efficacy numbers for adjuvant SRIF analog therapy (9-15).

Human GH-secreting pituitary adenomas express multiple sst subtypes. sst $_{2}$ and sst $_{5}$ receptors are the predominantly expressed sst, both at the mRNA (Table 1; (16-19)) and the protein level (20). Several studies reported a variable sst ${ }_{2}$ mRNA expression and a relatively high expression of $\mathrm{sst}_{5}(16,18,21)$. The $\mathrm{sst}_{2}$ seems a predominant receptor in determining the inhibitory effect of OCT or lanreotide on circulating $\mathrm{GH}$ release in acromegalic patients. sst $_{2}$ mRNA expression in GH-secreting pituitary adenomas shows a positive correlation with the in vivo GH suppression induced by an acute test using a single injection of $200 \mu \mathrm{g}$ OCT (21), as well as with the in vitro and in vivo responsiveness to OCT in another series of patients (18). Moreover, it has recently become clear that apart from $\mathrm{sst}_{2}, \mathrm{sst}_{5}$ receptors play an important role in regulating GH secretion by human GH-secreting pituitary adenoma cells as well. In this respect, the regulation of fetal human GH secretion (22) is similar to that in human GH-secreting pituitary adenomas. In primary cultures of human GH-secreting pituitary adenomas, new SRIFanalogs with enhanced sst $_{2}$-binding affinities inhibit GH secretion more potently compared with the clinically used octapeptide SRIF analogs, OCT and lanreotide. In addition, some adenomas show a better response to sst $_{2-}$ specific analogs, whereas in others sst $_{5}$-specific analogs are more potent in suppressing $\mathrm{GH}$ release (23). Moreover, the combined activation of $\mathrm{sst}_{2}$ and $\mathrm{sst}_{5}$ results in additive inhibitory effects on $\mathrm{GH}$ secretion. Interestingly, the sst ${ }_{5}$ preferential analog BIM-23 268 inhibited GH release in only 7 of 15 cases, whereas, in agreement with the results of Shimon and coworkers (23), partial additive effects in suppressing GH release were found in OCT-partially responding cultures when the sst $_{2^{-}}$and sst $_{5^{-}}$specific compounds were used in combination. Taking these data together, it can be concluded that $\mathrm{sst}_{2}$ is the predominant receptor in regulating $\mathrm{GH}$ release by GH-secreting pituitary adenoma cells, whereas sst $_{5}$ receptors may mediate an inhibitory effect on GH secretion as well. The additive inhibitory effects on $\mathrm{GH}$ release following activation of

Table 1 Percentage of human pituitary tumors expressing SRIF receptors.

\begin{tabular}{llllll}
\hline & \multicolumn{5}{c}{ SRIF receptor subtype } \\
\cline { 2 - 6 } Tumor type & $\mathrm{sst}_{1}$ & $\mathrm{sst}_{2}$ & $\mathrm{sst}_{3}$ & sst $_{4}$ & sst $_{5}$ \\
\hline Pituitary tumor & & & & & \\
$\quad$ Somatotrope & 44 & 96 & 44 & 5 & 86 \\
Lactotrope & 84 & 63 & 35 & 6 & 71 \\
Non-functioning & 38 & 75 & 43 & 13 & 48 \\
Corticotrope & 56 & 67 & 25 & 0 & 86 \\
\hline
\end{tabular}

The values represent the percentage of tumors expressing the sst subtype. both sst ${ }_{2}$ and sst ${ }_{5}$ are probably mediated via a functional association of both sst subtypes. Ren and coworkers (24) demonstrated in human fetal pituitary cell cultures that an sst ${ }_{2}$ selective antagonist was capable of reversing the $\mathrm{GH}$ suppressive effects of $\mathrm{sst}_{2} / \mathrm{sst}_{5}$ biselective agonists or that of sst $_{2}$ and sst ${ }_{5}$ agonists in combination, suggesting a functional interaction between both sst subtypes. In adenomas co-secreting GH and prolactin (PRL), PRL secretion is preferentially inhibited by sst $_{5}$-specific SRIF analogs $(16,18,23)$. The observed additive GH-suppressive effect of activating both sst $_{2}$ and sst $_{5}$ also initiated the development of analogs with selectivity to multiple sst subtypes. One of these compounds, the sst $_{2-}$ and sst $_{5}$-bispecific compound BIM-23 244, indeed inhibits GH release in a subgroup of partially OCTsensitive adenomas more potently when compared with OCT. In this subgroup of adenomas $\mathrm{sst}_{2}$ mRNA expression was ninefold lower, and sst $_{5}$ mRNA expression approximately sevenfold higher than in the OCT-sensitive adenomas (21). These studies suggest that in tumors expressing a low sst $_{2}$ level and a high sst $_{5} / \mathrm{sst}_{2}$ ratio, sst $_{5}$ is of increasing importance in regulating GH release (21). Another recently developed compound has a more universal sst-binding profile. This compound, named SOM230, has a 25-, 5- and 40 times higher binding affinity to $\mathrm{sst}_{1}, \mathrm{sst}_{3}$, and $\mathrm{sst}_{5}$ receptors respectively, and 2.5 times lower affinity to $\mathrm{sst}_{2}$, when compared with OCT (25). The SOM-230 inhibits GH release in a higher number of GH-secreting pituitary adenomas, both in vitro (18) and in vivo (see below). SOM230 suppressed GH secretion in primary cultures from human fetal pituitary cells (26). The preclinical reports of enhanced GH suppression via the combined activation of sst $_{2}$ and $\mathrm{sst}_{5}$ receptors in cultures of GH-secreting pituitary adenomas initiated a proofof-concept clinical trial with SOM230 in 12 patients with active acromegaly (27). A single s.c. injection of $250 \mu \mathrm{g}$ SOM230 compared with $100 \mu \mathrm{g}$ OCT showed comparable efficacy in suppressing circulating GH concentrations in eight patients, and showed a significantly enhanced suppression in 3 of 12 acromegalic patients (27; Fig. 1). The observation that SOM230 demonstrates potent inhibitory effects upon GH release in patients with GH-secreting pituitary adenomas expressing a low amount of sst $_{2}$ and a high amount of sst $_{5}$ suggests that the sst $_{5}$ subtype may indeed play an essential role in mediating in vivo $\mathrm{GH}$ suppressive actions in OCT-partial responders. Therefore, the enhanced efficacy of SOM230 can be explained by high sst ${ }_{5}$ expression in this type of adenomas and its 40-fold higher binding affinity for sst $_{5}$ as compared with OCT. Since SOM230 is able to lower GH levels in both OCT responders and partial responders, this novel SRIF analog has a clear advantage over OCT and might increase the number of patients that can be biochemically controlled during long-term medical treatment.

Finally, a role for $\mathrm{sst}_{1}$ in the control of GH-secreting pituitary adenoma cell function has been proposed. 
A

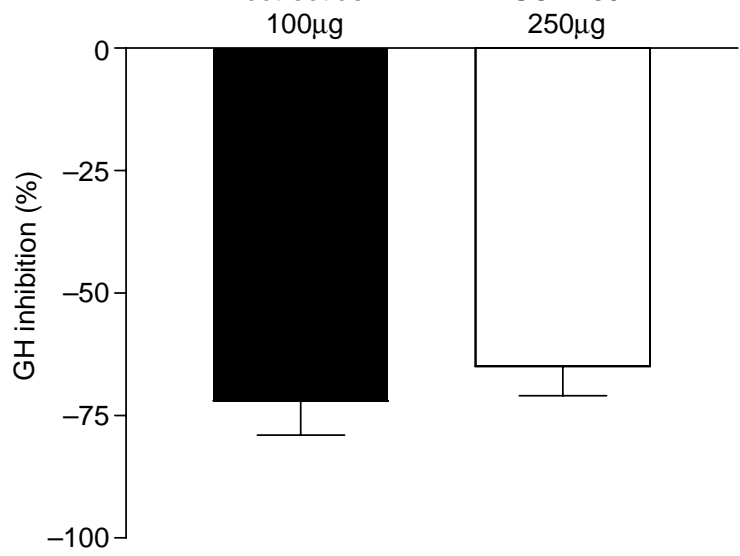

B

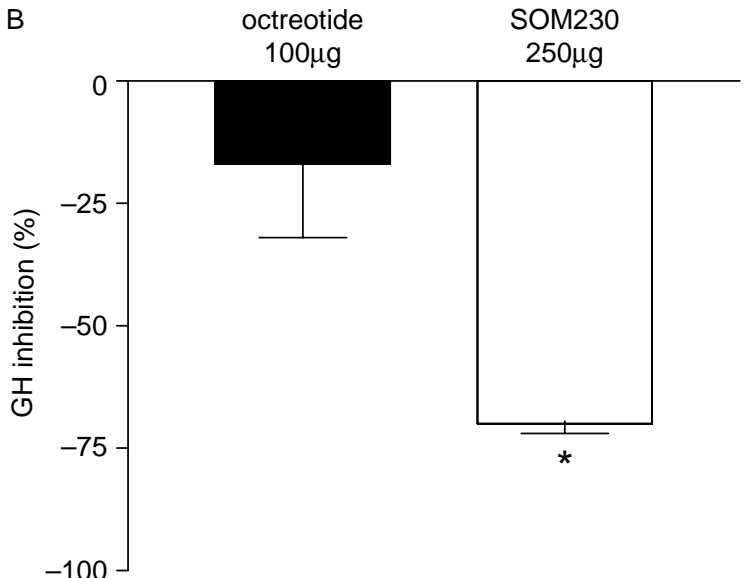

Figure 1 In vivo effects of SOM230 in acromegaly. The bars represent mean \pm S.E.M. percentage GH suppression induced by octreotide $100 \mu \mathrm{g}$ (black bars) and SOM230 $250 \mu \mathrm{g}$ (white bars) 2-8 $\mathrm{h}$ after s.c. injection compared with the control day. A: Group showing equal response to octreotide and $\operatorname{SOM} 230(n=8)$. B: Group showing higher sensitivity to SOM230 $\left(n=3\right.$; $\left.{ }^{\star} P<0.05\right)$. Adapted from (27).

Activation of $\mathrm{sst}_{1}$ receptors by the $\mathrm{sst}_{1}$-selective agonist BIM-23 296 results in a dose-dependent inhibitory effect in the nanomolar range on GH and PRL secretion by GH-secreting pituitary adenomas. In addition to lowering GH and PRL secretion this SRIF analog induced a decrease in cell viability as well (28). Moreover, BIM-23 745, another sst $_{1}$-selective agonist, was further demonstrated to significantly suppress $\mathrm{GH}$ secretion in vitro in a series of $\mathrm{GH}$-secreting pituitary adenomas from patients resistant or partially responsive to OCT or lanreotide in vivo (29).

\section{ACTH-secreting pituitary adenomas}

The endogenous Cushing's syndrome is predominantly caused by excess adrenocorticotropin (ACTH) release from an ACTH-secreting pituitary adenoma, also known as Cushing's disease (CD; (30)). Since significant mortality and morbidity accompany this condition, proper medical intervention is necessary. Transsphenoidal surgery is the treatment of choice for pituitary-dependent CD. Although transsphenoidal surgery allows cure of $\mathrm{CD}$, the reported success rates vary between 50 and 90\% (31-35). If surgery fails, radiotherapy, either alone or in combination with adrenolytic agents, may be used. Unfortunately, none of the current treatment modalities ensure a full and permanent cure, as the rate of recurrence of the disease, depending on the criteria of initial cure, varies between 5 and $24 \%$ in the literature $(36,37)$. Therefore, physicians have explored new medical strategies, preferably based on fundamental and (patho-)physiological pathways, with the hope to increase the chances of cure in this group of patients. Neuromodulatory agents, such as dopamine (DA) and SRIF, have been proposed to be of therapeutic interest in the medical treatment of CD. The conclusion of various case reports, however, is that the $s_{2} t_{2}$-preferring analog OCT is ineffective in treating CD (38-40). Recently, it was demonstrated that glucocorticoid treatment induces remarkable differences with respect to the role of $\mathrm{sst}_{2}$ and $\mathrm{sst}_{5}$ in regulating $\mathrm{ACTH}$ release in mouse corticotrope AtT-20 cells, predominantly expressing $\mathrm{sst}_{2}$ and sst $_{5}$ (41). In the absence of dexamethasone (DEX), OCT and SOM230 potently inhibited corticotropinreleasing hormone $(\mathrm{CRH})$-induced ACTH release, while the sst $_{5}$-specific analog BIM-23 268 appeared to be the least potent. In the presence of DEX, a physiological nanomolar concentration of SOM230 and BIM-23 268 still inhibited $\mathrm{CRH}$-induced ACTH release, whereas the suppressive effects of OCT were almost completely blocked. In addition, the $\mathrm{IC}_{50}$ values for OCT and BIM-23 268 after DEX treatment shift toward their $\mathrm{sst}_{5}$-binding affinity. The high potency for SOM230 was not affected by DEX. These data suggest down-regulation of $\mathrm{sst}_{2}$ by DEX, while $\mathrm{sst}_{5}$ receptors seem more resistant to DEX. This was indeed confirmed by the mRNA as well as by the sst membranebinding studies. These data suggest that in untreated patients with $\mathrm{CD}$ the expression level of $\mathrm{sst}_{2}$ is too low for OCT to lower ACTH and cortisol levels. Indeed, relatively low levels of sst $_{2}$ mRNA in a series of primary human corticotrope adenomas of patients with $\mathrm{CD}$ were found. On the other hand, a predominant expression of sst $_{5}$ mRNA in corticotrope adenomas was observed (42). This sst mRNA profile in human corticotrope adenomas, i.e. a low $\mathrm{sst}_{2}$ and a significant $\mathrm{sst}_{5}$ mRNA expression, supports the concept that glucocorticoids down-regulate $\mathrm{sst}_{2}$ expression in human corticotrope adenomas, while $\mathrm{sst}_{5}$ receptors are more resistant to glucocorticoid pressure. These observations also support the lack of efficacy of OCT in lowering circulating ACTH and cortisol levels in these patients, because $\mathrm{sst}_{2}$ expression is too low and $\mathrm{sst}_{5^{-}}$ membrane binding affinity of OCT is not high enough to make OCT therapeutically active in patients with CD. Support is formed by SOM230-induced inhibition of basal and $\mathrm{CRH}$-stimulated ACTH release by the corticotrophe adenomas, which appeared comparable with the observations in AtT20-cells, i.e. significant inhibition by SOM230 when compared with OCT, even in the presence 
of DEX. SOM230 did not inhibit AtT20 cell-proliferation or pro-opiomelanocortin synthesis during $72 \mathrm{~h}$ incubation in vitro. Therefore, increased ACTH breakdown may form an additional explanation for the inhibitory effect of SOM230 (and SRIF) on basal ACTH secretion. It is suggested, therefore, that $\mathrm{sst}_{2}+\mathrm{sst}_{5}$ preferring SRIF analogs, such as SOM230, might become of therapeutic interest in CD. The suppression of ACTH levels by activation of sst ${ }_{5}$ in patients with $\mathrm{CD}$ might lower cortisol levels. Since cortisol lowers $\mathrm{sst}_{2}$ expression, these suppressive effects might subsequently be (partially) abrogated, and enhanced ACTH inhibition via restored sst $_{2}$ expression becomes suggestive. Therefore, prolonged treatment with SOM230 may be able to lower ACTH levels in $\mathrm{CD}$ even more, because it could now function via both sst $_{5}$ and $\mathrm{sst}_{2}$ receptor subtypes (Fig. 2). An open label phase II trial in nine patients with untreated or recurrent CD has demonstrated promising results with SOM230 (43). After 2 weeks of SOM230 treatment, $600 \mu \mathrm{g}$ s.c. twice daily, free urinary cortisol levels normalized in three patients, while in the remaining six patients urinary cortisol levels were suppressed by $17-60 \%$. A prolonged treatment shall reveal whether this multiligand can indeed be of clinical potential for this serious neuroendocrine condition. On the other hand, glucose intolerance in all patients studied was documented during this short treatment period, and one patient even withdrew from the trial due to overt diabetes mellitus. In addition, a transient increase in glucose levels after SOM230 was already observed in acromegalic patients (44), whereby SOM230 was well tolerated and, in contrast to OCT, did not suppress insulin concentrations. Even though patients with CD and acromegaly are already known to suffer from glucose intolerance, it seems crucial for the future clinical development of SOM230 to retrieve answers with respect to this serious side effect.

\section{Prolactinomas}

Dopamine agonists have been shown to be highly effective in the medical treatment of PRL secreting pituitary adenomas $(45,46)$. Still, several patients seem intolerant for these drugs and some of them are resistant or partially responsive to DA agonist treatment. Therefore, can SRIF analogs become of interest to treat this small group of prolactinoma patients? In three DA agonist sensitive prolactinomas, SOM230 was significantly more potent than OCT in lowering PRL secretion in vitro (18). In two of the prolactinomas, there was a clear relationship between the expression of sst $_{5}$ mRNA in the adenoma cells and the percentage inhibition of PRL secretion by SOM230. In one prolactinoma culture, which expressed high levels of sst $_{5}$ mRNA and no other sst mRNAs, PRL secretion was reduced to the same extent as that induced by bromocriptine (Fig. 3). One other prolactinoma, which showed a significantly lower responsiveness to SOM230, had very low sst 5 mRNA levels. The lower potency of OCT in reducing PRL secretion by prolactinomas seems related to the very low $\mathrm{sst}_{2}$ levels as demonstrated in a series of 10 prolactinomas by Jaquet et al. (47). These data further underline the role of sst $_{5}$ in mediating its suppressive effect on PRL secretion. However, as already mentioned, the potential clinical importance of these findings should be considered in view of the very high proportion of patients with prolactinomas responding to DA agonist treatment with a normalization of PRL levels and tumor shrinkage (45, 46). In addition, Jaquet et al. (47) showed previously that the effects of $\mathrm{sst}_{5}$ selective compounds on prolactinoma cells are superimposable, at higher concentrations to those of the DA agonists, but not additive, particularly in adenomas resistant to dopaminergic suppression of PRL release.

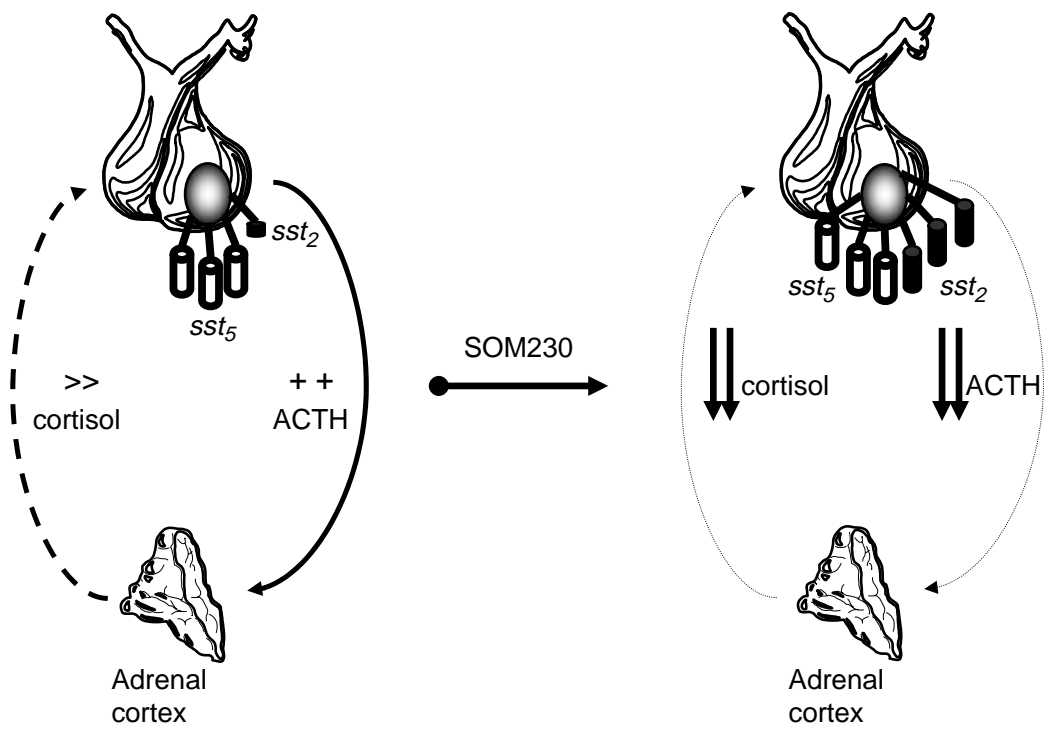

Figure 2 SOM230 in untreated pituitarydependent Cushing's disease. A de novo human corticotrophe adenoma has predominant expression of sst $_{5}$ and low expression of sst $_{2}$. The elevated ACTH and cortisol levels down-regulate $\mathrm{sst}_{2}$ expression on the tumor, making it almost impossible for the current clinically available sst $_{2}$-preferring SRIF-analogs to inhibit ACTH and cortisol secretion (left). SOM230, however, through activation of $\mathrm{sst}_{5}$, should be able to lower ACTH and cortisol levels. In this relative hypocortisolemic state, the down-regulation of $\mathrm{sst}_{2}$ by cortisol might be abrogated. Subsequently, because SOM230 also binds with good affinity to $s_{2}$, enhanced suppression of ACTH and cortisol via restored $\mathrm{sst}_{2}$ expression becomes suggestive (right). 

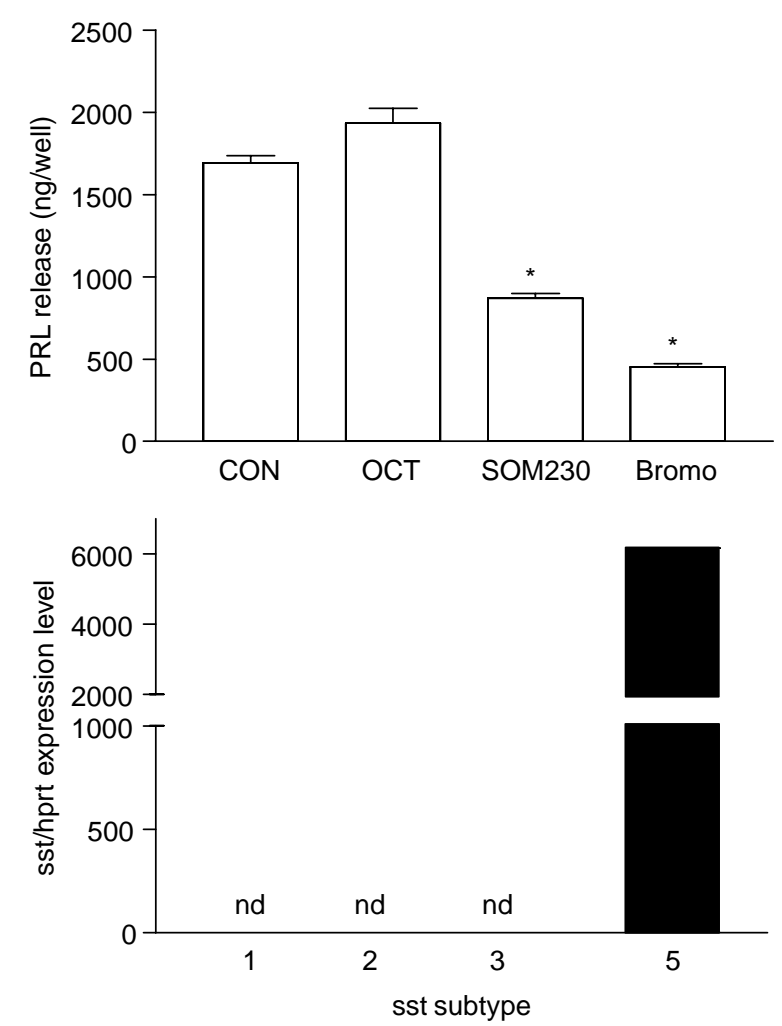

Figure 3 Upper: effects of SOM230 (10 nM), OCT $(10 \mathrm{nM})$ and bromocriptine $(10 \mathrm{nM})$ on $P R L$ release in a primary culture of a prolactinoma. ${ }^{*} P<0.01$ vs untreated control cells. Incubation time: $72 \mathrm{~h}$. Lower: sst subtype mRNA expression in the prolactinoma cells. Adapted from (18).

\section{TSH-secreting pituitary adenomas}

TSH-secreting pituitary adenomas are rare and transsphenoidal surgery is considered the first treatment approach for these tumors, leading to normalization of thyroid hormone levels and the disappearance of pituitary tumors in approximately $44 \%$ of patients $(48,49)$. The current clinically available SRIF analogs OCT and lanreotide induce normalization of thyroid hormone levels in the large majority of patients with TSH-secreting adenomas, although limited data are available. In approximately $80 \%$ of patients normalization of TSH levels has been reported, while significant tumor shrinkage is observed in $50 \%$ of cases (49-51). These data suggest that sst ${ }_{2}$ receptors seem to be involved in the beneficial effects of the current clinically available sst ${ }_{2}$-preferring SRIF analogs.

\section{Clinically non-functioning pituitary adenomas}

Clinically non-functioning pituitary adenomas (NFAs) represent a very heterogeneous group of tumors because a consistent proportion of them (up to 90\%) are shown to secrete low amounts of intact folliclestimulating hormone and luteinizing hormone and/or their $\alpha$ - and $\beta$-subunits either in vitro or in vivo. NFAs express sst subtypes, allowing researchers to attempt treatment with SRIF analogs. Despite favorable antiproliferative effects of OCT treatment on NFA cells in vitro, few clinical trials have been reported in NFAs, but tumor reduction was observed only in $11-13 \%$ of cases, indicating a weak correlation between sst expression and treatment efficacy with OCT in these patients (52). More recently, the suggested predominant expression of $\mathrm{sst}_{3} \mathrm{mRNA}$ in this group of pituitary adenomas (Hofland et al., unpublished data) and the in vitro support that $\mathrm{sst}_{3}$ can induce apoptosis via the induction of p53 and BAX (53), might reveal a new medical treatment option for patients with NFAs.

\section{Conclusion}

In the last two decades, SRIF analogs were used for the treatment of hormone-secreting pituitary adenomas. However, a significant proportion of these patients were found to be (partially) resistant to the suppressive effects of current clinically available sst $_{2}$-preferring SRIF analogs. With the improved understanding of SRIF and sst physiology and interactions, and with the increasing involvement of the industry in novel SRIF formulation production, well-characterized sst selective and universal SRIF analogs were developed. Using these novel SRIF analogs in in vitro pituitary cell cultures resulted in new concepts and potential mechanisms for the treatment of pituitary hormone hypersecretion. These concepts include ligand binding to both $\mathrm{sst}_{2}$ and $\mathrm{sst}_{5}$ or to sst $_{1}$ alone, resulting in greater efficacy to suppress GH in acromegaly; binding to $\mathrm{sst}_{5}$ to suppress PRL in prolactinomas; binding to predominantly $\mathrm{sst}_{5}$ and concomitantly to sst ${ }_{2}$ resulting in suppression of ACTH release in $\mathrm{CD}$; and finally, binding to $\mathrm{sst}_{3}$ might induce pituitary adenoma cell shrinkage in NFAs. In addition, interactions among sst subtypes and receptors of other G-protein coupled receptors, such as the dopamine D2 receptor, may form another therapeutic tool in the medical treatment of pituitary adenomas (54-59). This interactive multireceptor system of ligand activation and cross-talk at the membrane and intracellular levels may improve manipulation of pituitary hormone regulation, and enhance efficacy of medical therapy for pituitary hormone hypersecretion.

\section{References}

1 Melmed S, Jackson I, Kleinberg D \& Klibanski A. Current treatment guidelines for acromegaly. Journal of Clinical Endocrinology and Metabolism $1998 \mathbf{8 3} 2646-2652$.

2 Rajasoorya C, Holdaway IM, Wrightson P, Scott DJ \& Ibbertson HK. Determinants of clinical outcome and survival in acromegaly. Clinical Endocrinology 1994 41 95-102. 
3 Bauer W, Briner U, Doepfner W, Haller R, Huguenin R, Marbach P \& Petcher TJ. Pless. SMS 201-995: a very potent and selective octapeptide analogue of somatostatin with prolonged action. Life Sciences 198231 1133-1140.

4 Lamberts SW, Oosterom R, Neufeld M \& del Pozo E. The somatostatin analog SMS 201-995 induces long-acting inhibition of growth hormone secretion without rebound hypersecretion in acromegalic patients. Journal of Clinical Endocrinology and Metabolism $1985 \mathbf{6 0} 1161-1165$.

5 Lamberts SW, Uitterlinden P, Verschoor L, van Dongen KJ \& del Pozo E. Long-term treatment of acromegaly with the somatostatin analogue SMS 201-995. New England Journal of Medicine 1985313 1576-1580.

6 Reichlin S. Somatostatin. New England Journal of Medicine 1983 309 1495-1501.

7 Lamberts SW, van der Lely AJ, de Herder WW \& Hofland LJ. Octreotide. New England Journal of Medicine 1996334 246-254.

8 Freda PU. Somatostatin analogs in acromegaly. Journal of Clinical Endocrinology and Metabolism 200287 3013-3018.

9 Bevan JS, Atkin SL, Atkinson AB, Bouloux PM, Hanna F, Harris PE, James RA, McConnell M, Roberts GA, Scanlon MF, Stewart PM, Teasdale E, Turner HE, Wass JA \& Wardlaw JM. Primary medical therapy for acromegaly: an open, prospective, multicenter study of the effects of subcutaneous and intramuscular slow- release octreotide on growth hormone, insulin-like growth factor-I, and tumor size. Journal of Clinical Endocrinology and Metabolism 200287 4554-4563.

10 Attanasio R, Baldelli R, Pivonello R, Grottoli S, Bocca L, Gasco V, Giusti M, Tamburrano G, Colao A \& Cozzi R. Lanreotide 60 mg, a new long-acting formulation: effectiveness in the chronic treatment of acromegaly. Journal of Clinical Endocrinology and Metabolism $2003 \mathbf{8 8} 5258-5265$.

11 Colao A, Ferone D, Marzullo P, Cappabianca P, Cirillo S, Boerlin V, Lancranjan I \& Lombardi G. Long-term effects of depot long-acting somatostatin analog octreotide on hormone levels and tumor mass in acromegaly. Journal of Clinical Endocrinology and Metabolism $2001862779-2786$.

12 Ayuk J, Stewart SE, Stewart PM \& Sheppard MC. Long-term safety and efficacy of depot long-acting somatostatin analogs for the treatment of acromegaly. Journal of Clinical Endocrinology and Metabolism 200287 4142-4146.

13 Danoff A \& Kleinberg D. Somatostatin analogs as primary medical therapy for acromegaly. Endocrine 200320 291-298.

14 Sheppard MC. Primary medical therapy for acromegaly. Clinical Endocrinology $2003 \mathbf{5 8} 387-399$.

15 Newman CB, Melmed S, George A, Torigian D, Duhaney M, Snyder P, Young W, Klibanski A, Molitch ME, Gagel R, Sheeler L, Cook D, Malarkey W, Jackson I, Vance ML, Barkan A, Frohman L \& Kleinberg DL. Octreotide as primary therapy for acromegaly. Journal of Clinical Endocrinology and Metabolism 1998 83 3034-3040.

16 Jaquet P, Saveanu A, Gunz G, Fina F, Zamora AJ, Grino M, Culler MD, Moreau JP, Enjalbert A \& Ouafik LH. Human somatostatin receptor subtypes in acromegaly: distinct patterns of messenger ribonucleic acid expression and hormone suppression identify different tumoral phenotypes. Journal of Clinical Endocrinology and Metabolism 200085 781-792.

17 Murabe H, Shimatsu A, Ihara C, Mizuta H, Nakamura Y, Nagata I, Kikuchi H \& Nakao K. Expression of somatostatin receptor (SSTR) subtypes in pituitary adenomas: quantitative analysis of SSTR2 mRNA by reverse transcription- polymerase chain reaction. Journal of Neuroendocrinology 19968 605-610.

18 Hofland LJ, van der Hoek J, van Koetsveld PM, de Herder WW, Waaijers M, Sprij-Mooij D, Bruns C, Weckbecker G, Feelders R, van der Lely AJ, Beckers A \& Lamberts SW. The novel somatostatin analog SOM230 is a potent inhibitor of hormone release by growth hormone- and prolactin-secreting pituitary adenomas in vitro. Journal of Clinical Endocrinology and Metabolism 200489 $1577-1585$.
19 Hofland LJ \& Lamberts SW. The pathophysiological consequences of somatostatin receptor internalization and resistance. Endocrine Reviews $20032428-47$.

20 Reubi JC, Waser B, Schaer JC \& Laissue JA. Somatostatin receptor sst1-sst 5 expression in normal and neoplastic human tissues using receptor autoradiography with subtype-selective ligands. European Journal of Nuclear Medicine 200128 836-846.

21 Saveanu A, Gunz G, Dufour H, Caron P, Fina F, Ouafik L, Culler MD, Moreau JP, Enjalbert A \& Jaquet P. Bim-23244, a somatostatin receptor subtype 2- and 5-selective analog with enhanced efficacy in suppressing growth hormone (GH) from octreotide-resistant human GH-secreting adenomas. Journal of Clinical Endocrinology and Metabolism 200186 140-145.

22 Shimon I, Taylor JE, Dong JZ, Bitonte RA, Kim S, Morgan B, Coy DH, Culler MD \& Melmed S. Somatostatin receptor subtype specificity in human fetal pituitary cultures. Differential role of SSTR2 and SSTR5 for growth hormone, thyroid-stimulating hormone, and prolactin regulation. Journal of Clinical Investigation $199799789-798$.

23 Shimon I, Yan X, Taylor JE, Weiss MH, Culler MD \& Melmed S. Somatostatin receptor (SSTR) subtype-selective analogues differentially suppress in vitro growth hormone and prolactin in human pituitary adenomas. Novel potential therapy for functional pituitary tumors. Journal of Clinical Investigation $1997 \mathbf{1 0 0}$ 2386-2392.

24 Ren SG, Taylor J, Dong J, Yu R, Culler MD \& Melmed S. Functional association of somatostatin receptor subtypes 2 and 5 in inhibiting human growth hormone secretion. Journal of Clinical Endocrinology and Metabolism $2003 \mathbf{8 8} 4239-4245$.

25 Bruns C, Lewis I, Briner U, Meno-Tetang G \& Weckbecker G. SOM230: a novel somatostatin peptidomimetic with broad somatotropin release inhibiting factor (SRIF) receptor binding and a unique antisecretory profile. European Journal of Endocrinology 2002146 707-716.

26 Murray RD, Kim K, Ren SG, Lewis I, Weckbecker G, Bruns C \& Melmed S. The novel somatostatin ligand (SOM230) regulates human and rat anterior pituitary hormone secretion. Journal of Clinical Endocrinology and Metabolism 200489 3027-3032.

27 van der Hoek J, de Herder WW, Feelders RA, van der Lely AJ, Uitterlinden P, Boerlin V, Bruns C, Poon KW, Lewis I, Weckbecker G, Krahnke T, Hofland LJ \& Lamberts SW. A single-dose comparison of the acute effects between the new somatostatin analog SOM230 and octreotide in acromegalic patients. Journal of Clinical Endocrinology and Metabolism $200489638-645$.

28 Zatelli MC, Piccin D, Tagliati F, Ambrosio MR, Margutti A, Padovani R, Scanarini M, Culler MD \& degli Uberti EC. Somatostatin receptor subtype 1 selective activation in human growth hormone (GH)- and prolactin (PRL)-secreting pituitary adenomas: effects on cell viability, GH, and PRL secretion. Journal of Clinical Endocrinology and Metabolism $2003 \mathbf{8 8}$ 2797-2802.

29 Matrone C, Pivonello R, Colao A, Cappabianca P, Cavallo LM, Del Basso De Caro ML, Taylor JE, Culler MD, Lombardi G, Di Renzo GF \& Annunziato L. Expression and function of somatostatin receptor subtype 1 in human growth hormone secreting pituitary tumors deriving from patients partially responsive or resistant to longterm treatment with somatostatin analogs. Neuroendocrinology $200479142-148$.

30 Newell-Price J, Trainer P, Besser M \& Grossman A. The diagnosis and differential diagnosis of Cushing's syndrome and pseudoCushing's states. Endocrine Reviews 199819 647-672.

31 Mampalam TJ, Tyrrell JB \& Wilson CB. Transsphenoidal microsurgery for Cushing disease. A report of 216 cases. Annals of Internal Medicine $1988 \mathbf{1 0 9} 487-493$.

32 Swearingen B, Biller BM, Barker FG, II, Katznelson L, Grinspoon S, Klibanski A \& Zervas NT. Long-term mortality after transsphenoidal surgery for Cushing disease. Annals of Internal Medicine $1999130821-824$.

33 Trainer PJ, Lawrie HS, Verhelst J, Howlett TA, Lowe DG, Grossman AB, Savage MO, Afshar F \& Besser GM. Transsphenoidal 
resection in Cushing's disease: undetectable serum cortisol as the definition of successful treatment. Clinical Endocrinology $1993 \mathbf{3 8}$ 73-78.

34 Knappe UJ \& Ludecke DK. Persistent and recurrent hypercortisolism after transsphenoidal surgery for Cushing's disease. Acta Neurochirurgica. Supplement 199665 31-34.

35 Boggan JE, Tyrrell JB \& Wilson CB. Transsphenoidal microsurgical management of Cushing's disease. Report of 100 cases. Journal of Neurosurgery 198359 195-200.

36 Sonino N, Zielezny M, Fava GA, Fallo F \& Boscaro M. Risk factors and long-term outcome in pituitary-dependent Cushing's disease. Journal of Clinical Endocrinology and Metabolism $1996 \mathbf{8 1}$ 2647-2652.

37 Miller JW \& Crapo L. The medical treatment of Cushing's syndrome. Endocrine Reviews $199314443-458$.

38 Lamberts SW, Uitterlinden P \& Klijn JM. The effect of the longacting somatostatin analogue SMS 201-995 on ACTH secretion in Nelson's syndrome and Cushing's disease. Acta Endocrinologica $1989120760-766$.

39 Stalla GK, Brockmeier SJ, Renner U, Newton C, Buchfelder M, Stalla J \& Muller OA. Octreotide exerts different effects in vivo and in vitro in Cushing's disease. European Journal of Endocrinology $1994130125-131$.

40 Ambrosi B, Bochicchio D, Fadin C, Colombo P \& Faglia G. Failure of somatostatin and octreotide to acutely affect the hypothalamicpituitary-adrenal function in patients with corticotropin hypersecretion. Journal of Endocrinological Investigation 199013 257-261.

41 van der Hock J, Waaijers A, van Koetsveld P, Sprij-Mooij D, Feelders RA, Schmid HA, PS, Hoyer D, Cervia D, JET, MDC, Lamberts SWJ \& Hofland LJ. Distinct functional properties of native somatostatin receptor subtype 5 compared with subtype 2 in the regulation of ACTH release by corticotroph tumor cells. American Journal of Physiology, Endocrinology and Metabolism 2005 289 E2 78-E287.

42 Hofland LJ, van der Hoek J, Feelders R, van Aken MO, van Koetsveld PM, Waaijers M, Sprij-Mooij D, Bruns C, Weckbecker G, de Herder WW, Beckers A \& Lamberts SWJ. The multiligand somatostatin analog SOM230 inhibits ACTH secretion by cultured human corticotroph adenomas via somatostatin receptor subtype 5. European Journal of Endocrinology $2005152645-654$.

43 Boscaro M, Brew Atkinson A, Bertherat J, Petersenn S, Glusman JE, Gao B \& Tran LL. Early data on the efficacy and safety of the novel multi-ligand somatostatin analog, SOM230, in patients with Cushing's disease. The Endocrine Society Meeting, 2005 P2-531.

44 van der Hoek J, van der Lely AJ, Feelders RA, de Herder WW, Uitterlinden P, Poon KW, Boerlin V, Lewis I, Krahnke T, Hofland LJ \& Lamberts SW. The somatostatin analog SOM230, compared with octreotide, induces differential effects in several metabolic pathways in acromegalic patients. Clinical Endocrinology 200563 $176-184$

45 Colao A, di Sarno A, Pivonello R, di Somma C \& Lombardi G. Dopamine receptor agonists for treating prolactinomas. Expert Opinion on Investigational Drugs 200211 787-800.

46 Webster J. Clinical management of prolactinomas. Baillieres Best Practice and Research. Clinical Endocrinology and Metabolism 1999 13 395-408.

47 Jaquet P, Ouafik L, Saveanu A, Gunz G, Fina F, Dufour H, Culler MD, Moreau JP \& Enjalbert A. Quantitative and functional expression of somatostatin receptor subtypes in human prolactinomas. Journal of Clinical Endocrinology and Metabolism 199984 3268-3276.
48 Beck-Peccoz P, Brucker-Davis F, Persani L, Smallridge RC \& Weintraub BD. Thyrotropin-secreting pituitary tumors. Endocrine Reviews 199617 610-638.

49 Beck-Peccoz P, Persani L, Mantovani S, Cortelazzi D \& Asteria C. Thyrotropin-secreting pituitary adenomas. Metabolism $1996 \mathbf{4 5}$ 75-79.

50 Comi RJ, Gesundheit N, Murray L, Gorden P \& Weintraub BD. Response of thyrotropin-secreting pituitary adenomas to a longacting somatostatin analogue. New England Journal of Medicine $198731712-17$.

51 Chanson P, Weintraub BD \& Harris AG. Octreotide therapy for thyroid-stimulating hormone-secreting pituitary adenomas. A follow-up of 52 patients. Annals of Internal Medicine 1993119 236-240.

52 Colao A, Filippella M, Somma C, Manzi S, Rota F, Pivonello R, Gaccione M, Rosa M \& Lombardi G. Somatostatin analogs in treatment of non-growth hormone-secreting pituitary adenomas. Endocrine 200320 279-284.

53 Sharma K, Patel YC \& Srikant CB. Subtype-selective induction of wild-type p53 and apoptosis, but not cell cycle arrest, by human somatostatin receptor 3. Molecular Endocrinology 1996 10 1688-1696.

54 Baragli A, Kumar U, Patel R C, Patel Y C. Hetero-oligomerisation of dopamine (D2R) and somatostatin receptors (sstr2) in CHO-K1 cells and cortical cultures neurons. 2003 In Proceedings of the 85th Annual Meeting of the Endocrine Society. Philadelphia, 2003, p 2469.

55 George SR, O'Dowd BF \& Lee SP. G-protein-coupled receptor oligomerization and its potential for drug discovery. Nature Reviews. Drug Discovery $20021808-820$.

56 Jaquet P, Gunz G, Saveanu A, Dufour H, Taylor J, Dong J, Kim S, Moreau JP, Enjalbert A \& Culler MD. Efficacy of chimeric molecules directed towards multiple somatostatin and dopamine receptors on inhibition of $\mathrm{GH}$ and prolactin secretion from GH-secreting pituitary adenomas classified as partially responsive to somatostatin analog therapy. European Journal of Endocrinology 2005153 135-141.

57 Jaquet P, Gunz G, Saveanu A, Barlier A, Dufour H, Taylor J, Dong J, Kim S, Moreau JP \& Culler MD. BIM-23A760, a chimeric molecule directed towards somatostatin and dopamine receptors, vs universal somatostatin receptors ligands in GH-secreting pituitary adenomas partial responders to octreotide. Journal of Endocrinological Investigation $2005 \mathbf{2 8}$ 21-27.

58 Ren SG, Kim S, Taylor J, Dong J, Moreau JP, Culler MD \& Melmed S. Suppression of rat and human growth hormone and prolactin secretion by a novel somatostatin/dopaminergic chimeric ligand. Journal of Clinical Endocrinology and Metabolism 200388 5414-5421.

59 Saveanu A, Lavaque E, Gunz G, Barlier A, Kim S, Taylor JE, Culler MD, Enjalbert A \& Jaquet P. Demonstration of enhanced potency of a chimeric somatostatin-dopamine molecule, BIM23A387, in suppressing growth hormone and prolactin secretion from human pituitary somatotroph adenoma cells. Journal of Clinical Endocrinology and Metabolism 200287 5545-5552.

Received 12 January 2007

Accepted 18 January 2007 